\title{
Democracy at a TTIP'ing point Seizing a slim chance to reassert democratic sovereignty in Europe
}

Colin Crouch, who first diagnosed and described our 'post-democratic' malaise a decade ago, assesses the strength of recent democratic interventions in the previously closed-shop TTIP negotiations as a reaction to deepening crises of popular mistrust and political capture in European and western democratic national polities.

Suddenly, the Transatlantic Trade and Investment Partnership (TTIP) has found itself at the centre of controversy, and the way the debate is going tells us a great deal about politics in our 'post-democratic' societies. On the one side, an elite of business and governmental persons has been trying to make deals behind the back of the population - potentially undermining a mass of social and environmental policies - and in particular planning to enable tribunals of private corporate lawyers to judge corporations' complaints against governments' policies. This is post-democracy in its purest form. On the other side, an array of civil society groups, together with green and other smaller parties, are rallying opposition, mobilising the popular mistrust of these elites that postdemocratic politics itself has generated. The outcome remains uncertain, but enough has already happened to show that trends towards postdemocracy remain strong but are - for now at least - contested.

In brief, TTIP is a plan for a major relaxation of barriers to trade between member states of the European Union and the United States. Most tariff barriers have already been negotiated away in various global agreements. What remain are the so-called non-tariff barriers. These extend from rules that are clearly intended solely to keep international competitors out of domestic markets, to regulations seriously designed to protect health, labour rights and various concepts of public and collective goods. It is over these latter issues that alarm bells have been ringing.

In post-democratic societies, all the formal institutions of democracy - elections, open debate, changes of government - survive but cease to be the focal point of political dynamism. Instead, this is relocated in small, private circles where political elites do deals with corporate lobbies. In my book Post-Democracy (Polity Press, 2004) I argued that in many western societies we were on the road towards post-democracy but had not yet arrived, as our democratic politics still had life and energy. I was writing before the financial crisis of 2007/08 and consequent crisis in the eurozone, and the concentration of attempted resolutions to these crises on small groups of officials and bankers. I was also writing before TTIP. 
These developments all suggest that in the 10 years since Post-Democracy we have progressed considerably further along that road.

\section{THE THREAT OF TTIP}

In terms of what TTIP seeks to change, three issues make it disturbing.

First, there are substantive fears that the compromises involved in reconciling EU and US standards will lead to an overall decline in regulation that protects us against such things as the degrading of labour rights, irresponsible banks, and inadequate testing of chemical additives in food, pharmaceuticals and cosmetics. This is partly because any compromise between a higher set of standards and a lower one necessarily implies loss for those starting at the higher level. But partly it is also because, in the present business-dominated climate, we know that the most powerful interests will be pushing to use this negotiation to aim for a new, generally lower level of regulation and protection of standards. The European Commission's website, which passionately advocates for TTIP, is replete with statements about creating European jobs. This, of course, is the highly familiar, indeed routine, corporate blackmailer's coded threat: 'Give up your health, labour and environmental standards or we shall go away and leave masses of you unemployed!'

Usually it is Europeans who have more to fear than Americans from such compromises, as often our standards are higher, as corporate lobbies in the US have been longer at their game and better funded than those in most European countries or within the EU's own institutions. This is not always the case, however: US courts and administration are being considerably tougher on banking behaviour, for instance, than the EU will be (at least if the UK gets its way). Also, EU policy is increasingly being influenced by governments in central and eastern Europe, whose economies are necessarily competing down-market, and many of whose politicians see any social policy as a return to state socialism. The issue of standardising regulations is, therefore, only partly one of 'social Europe versus market America', and so as a result this is not a particularly helpful way to frame the problem.

The second major concerns centres on the risk that European health, education and other public services will be partly privatised and contracted out to US corporations. This is already well underway in the UK and some other member states, without any need for TTIP, but other countries are still trying to protect the idea of publicly provided public services in certain fields. Their efforts have already been eroded by recent developments in EU competition policy, even without any push from US interests. Again, US firms are more adept at this game, because their country's small welfare state has allowed more scope for profit-making social policy, but European firms are active here too.

Under current EU competition law it remains possible for governments to declare certain areas of social policy to sit outside the market economy, defining them as services of general economic interest. Nonetheless, in practice, their attempts to do so remain vulnerable to legal challenges 
from corporations. For example, the Dutch government reserved its social housing sector, which is unusually large, making up almost a third of their housing stock. Building firms argued before the European Court of Justice that this proportion was too high. Although the dispute is not yet resolved after more than eight years in process, the court's approach has been to insist on a reduction of the size of the social housing sector in the Netherlands, thereby taking it on itself to decide a substantive matter of national social policy. ${ }^{1}$

It is highly likely that the terms of TTIP would reinforce this vulnerability of government attempts to reserve areas of social policy from the market, as one of its central provisions is to facilitate firms' ability to claim redress against government actions that can be said to threaten their profits. Here again a trade treaty with the US seems to be reinforcing pressures already at work within Europe, rather than some distinctively American threat.

The current negotiating position of the EU in TTIP is to leave it to the discretion of national governments whether areas like national health services are kept outside the scope of traded services. ${ }^{2}$ But what would happen if a neoliberal government declared its health service to be tradable within TTIP, only to be followed by a social democratic one that wanted to reverse that decision? Would foreign health firms be able to sue on the grounds that a policy change had damaged their interests? This cannot be known until after the full text of a treaty has been agreed and lawyers have had a chance to comb through it.

The third major issue focusses on the means by which firms would claim redress against governments if they act in ways that threaten their investments and profits. To this end, TTIP proposes a procedure known as investor-state dispute settlement (ISDS). A key focus of controversy here has been that such procedures do not use normal law courts with established judges, but arbitration panels comprised solely of corporate lawyers - people who earn most of their money working for corporations. Indeed, this is not so much post-democracy, as post-law.

Over and above these specific issues, those concerned about them have made much of the fact that preparation of the EU bargaining position and the negotiations themselves have taken place in secret. Corporate interests are presumably consulted, because it is primarily their interests that are being advanced. On the flipside, the Commission has stated (note the 'jobs' blackmail) that:

'The Commission will also communicate in a transparent manner with representatives of the Civil Society on this trade agree ment. However, this will also be balanced with a certain level of confidentiality in trade negotiations, which is required in order not to compromise the EU's objectives in this deal-which is in the end to create jobs for Europeans.'

1 For details, see Sol CCAM and Van der Vos MR (2012) 'Mapping the wording of EU-proof social housing: the case of the EC versus the Member State of the Netherlands', Gusto Project. http://www.gusto-project.eu/ index.php?option=\%20com_content\&view=article\&id=336:paper\&catid=44:wp5\&ltemid=61.

2 This was clarified in a letter from the EU's chief negotiator, Ignacio Garcia Bercero, in a letter to Labour MP John Healey, who is chair of the UK parliament's committee on TTIP. See Watt N (2014) 'European official commits to safeguarding NHS in EU-US trade deal', Guardian, 11 July 2014. http://www.theguardian.com/society/2014/ jul/11/nhs-safeguarded-european-commission-eu-us-trade-deal.

"A key focus of
controversy has
been that ISDS
procedures do
not use normal
law courts but
arbitration panels
comprised solely
of corporate
lawyers... This
is not so much
post-democracy
as post-law."

“A key focus of controversy has been that ISDS procedures do not use normal law courts but arbitration panels comprised solely of corporate lawyers... This is not so much as post-law." 
Of course, the EU parliament and member states will also have a chance to vote on the final package, but by comparison with the opportunities given to business interests to shape proposals at every step along the way, any such vote is a blunt instrument indeed.

\section{DEMOCRACY STRIKES BACK?}

In these respects, then, TTIP presents a textbook example of trends towards post-democracy. However, the recent controversy surrounding it also demonstrates that, unless they have become totally powerless, social groups will react against an action hostile to their interests (though not necessarily successfully). At the centre of conflict so far has been the ISDS proposal. The basic idea behind ISDS is not unreasonable: firms investing in a country need some protection from state action that might fundamentally threaten those investments; otherwise they cannot risk making them in the first place. Some governments - usually in poor countries, wishing to attract investment and seeking to reassure foreign corporations about their long-term intentions or to protect firms from future upheavals - have been willing to accept arbitration in such cases by tribunals of corporate lawyers. The issues originally at stake concerned such matters as the risk of expropriation, being the confiscation of assets without compensation. It is certainly understandable why firms sought reassurance and why governments sought to provide it, and possible even to see why the tribunal of lawyers was devised as a forum for resolving such disputes.

Inevitably, however, where the interests of giant corporations and their resourceful lawyers are involved, there has been mission creep. There are two frequently cited ongoing cases. Vattenfall, a Swedish nuclear energy firm, is taking the German government through an ISDS process because, in the wake of the Fukushima power station incident in Japan, it decided to phase out nuclear energy, and in doing so closed a plant part-owned by Vattenfall. Elsewhere, Philip Morris, the US cigarette manufacturer, is trying to prevent governments in Australia and other countries from taking active measures to persuade their populations not to smoke. In these cases, the matters at hand are a far cry from expropriation; indeed, they seek to extend the concept to include any actions by governments that might reduce the profits of foreign investors.

If successful, these actions will be the most blatant attack so far by global firms on political democracy. Even without TTIP, they would set an extraordinary antidemocratic precedent; the treaty would only spread their potential implications far more widely. These cases have not yet been decided, as advocates of ISDS as part of TTIP are keen to stress; the firms' lawyers are seeking considerable stretch in the meaning of these arrangements, and might well fail. Nevertheless, the Dutch social housing case shows that such creep can occur, and, whatever assurances are being given now, opponents of ISDS have every reason to be suspicious that similar developments could occur at some point in the future.

\section{“TTIP presents a textbook example of trends towards post-democracy. However, the recent controversy surrounding it also demonstrates that, unless they have become totally powerless, social groups will react against an action hostile to their interests."}


Nevertheless, the fact that assurances are being offered has shown democracy's capacity at least to expose these previously very secretive negotiations to open debate. The new EU Commission president, Jean-Claude Juncker, has made it abundantly clear that in his view there is no reason why established law courts should not deal with these disputes, rather than tribunals of corporate lawyers. However, one must remain continuously on guard: Juncker is under pressure from some governments and commission colleagues to stick with the original formulation. In any case, established law courts are also susceptible to corporate persuasion, as the European court repeatedly shows.

The struggle over different components of TTIP will continue for some time. Already, the tone of the commission's arguments has become increasingly defensive. Democracy has raised its head within what negotiators thought would be an untroubled see of technical discussion and corporate lobbying. On both sides of the Atlantic, parliamentarians have expressed displeasure at their exclusion from such a fundamental series of negotiations. This intervention has a bitter-sweet aspect to it: much of the furore, suspicion and demand for openness reflects the widespread mistrust of both politics (nationally and at the European level) and the political activities of big business. Large sections of the general public are unwilling to accept the good faith of those claiming to work on their behalf. This marks a gain in political maturity, but it is not sustainable basis for such maturity in the long term. If mistrust spirals out of control it breeds cynicism, demobilises any attempt at collective action, and plays into the hands of populist extremists. This may well be the first stage of a reaction against postdemocracy, but it is a deeply unsatisfactory one.

\section{BEYOND THE TTIP CONFLICT}

It is important that critics of TTIP focus on the core issue: corporations using their lobbying power and a 'threat to jobs' mantra to whittle down social standards previously built up during a period when democracy was more vibrant. It is neither a question of Europe versus the US, nor of 'Brussels' versus member states. On the contrary, behind the free-trade rhetoric of US politics stands a mass of special protected interests, while in Europe the UK government, so loud in its claims for national sovereignty, is among the most enthusiastic about surrendering social standards to TTIP.

Following a recent meeting on the treaty in Washington, DC, with US colleagues, the Foundation for European Progressive Studies set out 10 key action points for European progressive parties. One of these action points stressed that developing a coherent European strategy on TTIP requires a full intra-European understanding on social policy priorities; the alternative - a division of labour by which the EU deals with trade in isolation while member states try to defend social policy - would be disastrous, as regional trade policy would eventually override 'softer' national social agendas.

This argument should be particularly salient for those who favour some kind of trans-Atlantic or even wider trade treaty. Breaking down barriers to trade has repeatedly shown its capacity, given various safeguards and transitional

\section{"This may well be the first stage of a reaction against post- democracy, but it is a deeply unsatisfactory one."}


measures, to serve many interests. We can already see how the entry of China and other Asian countries into world trade is advancing the welfare of millions of people in parts of the world previously sunk in unrelieved poverty, while also bringing new opportunities to businesses in the existing wealthy countries. The centre-left needs to resist the knee-jerk urge to oppose any move to liberate trade. Indeed, just as we worry about the mission creep of measures that strengthen corporations' power at law, we should be concerned at pure protectionism masquerading as social policy and standing in the way of a good trade deal. There is a long history of that approach in all jurisdictions.

Limiting it requires a clear understanding of what constitutes the field of social policy and its proper objectives. (Europe needs this anyway if it is to get beyond blind, indiscriminate austerity in its approach to the south-western states involved in the eurozone crisis.) There has to be recognition that not all areas of social life should be open to the market, but these have to be defined with a clear rationale. Only a few extreme neoliberal economists advocate a legal market in human organs for transplants, for instance; on the other hand, broad swathes of public opinion would probably favour health in general and much other care work and education to be similarly off-limits. There needs to be a general framework agreement on how these limits should be defined, to enable brute protectionism to be distinguished from principled concepts of the scope for the social and the ethical to challenge the sovereignty of the economic. In its turn, such a framework should not extend so far as to crush debate about one of the most fundamental legitimate fields of conflict within democratic politics.

A democratic, openly debated approach to such measures as TTIP would not be confined to widening trade by reducing regulation, but could do the opposite: partners could agree to reduce barriers if the other side brings its standards up, not down. The US might offer to adopt European standards on, say, food additives or workers' consultation rights in exchange for tougher banking rules in Europe.

We stand at a tricky juncture. There is a serious danger that the pessimists will be right, that the corporate lobbies of post-democracy will produce a TTIP that sweeps away a mass of protective regulations for consumers, workers and the community at large, to the long-term detriment of our welfare. There is, however, a slim chance that instead we shall have a new appreciation of the need for and scope of transnational democratic action, with expanded world trade and the development of an intelligent pan-European approach to social policy.

Colin Crouch is a sociologist and political scientist, and is currently emeritus professor at the University of Warwick.
"The centre-left

needs to resist

the knee-jerk urge

to oppose any move

to liberate trade.

Indeed, just as

we worry about

the mission creep

of measures

that strengthen

corporations'

power at law,

we should be

concerned at pure

protectionism

masquerading

as social policy

and standing

in the way of a

good trade deal." 